Understanding and Profiting from Intellectual Property 
Also by Deli Yang

INTELLECTUAL PROPERTY AND DOING BUSINESS IN CHINA 


\section{Understanding and Profiting from Intellectual Property}

A guide for Practitioners and Analysts

Deli Yang 


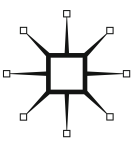

(C) Deli Yang 2008

Softcover reprint of the hardcover 1st edition 2008 978-1-4039-9172-0

All rights reserved. No reproduction, copy or transmission of this publication may be made without written permission.

No paragraph of this publication may be reproduced, copied or transmitted save with written permission or in accordance with the provisions of the Copyright, Designs and Patents Act 1988, or under the terms of any licence permitting limited copying issued by the Copyright Licensing Agency, 90 Tottenham Court Road, London W1T 4LP.

Any person who does any unauthorized act in relation to this publication may be liable to criminal prosecution and civil claims for damages.

The author has asserted her right to be identified as the author of this work in accordance with the Copyright, Designs and Patents Act 1988.

First published 2008 by PALGRAVE MACMILLAN

Houndmills, Basingstoke, Hampshire RG21 6XS and 175 Fifth Avenue, New York, N.Y. 10010

Companies and representatives throughout the world

PALGRAVE MACMILLAN is the global academic imprint of the Palgrave Macmillan division of St. Martin's Press, LLC and of Palgrave Macmillan Ltd. Macmillan ${ }^{\circledR}$ is a registered trademark in the United States, United Kingdom and other countries. Palgrave is a registered trademark in the European Union and other countries.

ISBN 978-1-349-54316-8 ISBN 978-0-230-58207-1 (eBook) DOI $10.1057 / 9780230582071$

This book is printed on paper suitable for recycling and made from fully managed and sustained forest sources. Logging, pulping and manufacturing processes are expected to conform to the environmental regulations of the country of origin.

A catalogue record for this book is available from the British Library.

A catalog record for this book is available from the Library of Congress.

$\begin{array}{llllllllll}10 & 9 & 8 & 7 & 6 & 5 & 4 & 3 & 2 & 1\end{array}$

$\begin{array}{llllllllll}17 & 16 & 15 & 14 & 13 & 12 & 11 & 10 & 09 & 08\end{array}$ 
Tribute to Star Moon

For my Family and my Soul Pals 


\section{Brief Contents}

List of Tables xiii

List of Figures xiv

List of Photos $x v$

List of Opener and Closer Cases $\quad x v i$

List of Intellectual Property Facts xvii

List of Abbreviations and Acronyms xviii

Preface and Acknowledgements xxi

Chapter 1: Understanding and Profiting from Intellectual Property: A Beginning 1

Part I: Intellectual Property Fundamentals 11

Chapter 2: Intellectual Property Theories 13

Chapter 3: Intellectual Property Systems 39

Part II: Intellectual Property Environments $\quad 69$

Chapter 4: The Effects of Intellectual Property on Political Economy $\quad 71$

Chapter 5: The Effects of Political Economy on Intellectual Property 99

Chapter 6: The Effects of Culture on Intellectual Property 116

Part III: Intellectual Property Management 135

Chapter 7: Managing Intellectual Property Assets 137

Chapter 8: Valuing Intellectual Property 162

Part IV: Intellectual Property Strategies 187

Chapter 9: Commercializing Intellectual Property Internationally 189

Chapter 10: Licensing and Contracting Intellectual Property Internationally 219

Chapter 11: Global Piracy and Strategic Responses 251

Chapter 12: Understanding and Profiting from Intellectual Property: New Beginnings 286

Index 


\section{Contents}

List of Tables xiii

List of Figures xiv

List of Photos $x v$

List of Opener and Closer Cases xvi

List of Intellectual Property Facts xvii

List of Abbreviations and Acronyms xviii

Preface and Acknowledgements xxi

Chapter 1: Understanding and Profiting from

Intellectual Property: A Beginning $\quad 1$

Focus and structure

1.1 Aims and purposes

1.2 Rationale and intended readership 2

1.3 Methodological delineation 3

1.4 Structure and thematic overview 5

A beginning: A route map for the book 9

Note 10

Part I: Intellectual Property Fundamentals 11

Chapter 2: Intellectual Property Theories 13

Focus and structure $\quad 13$

Opener: Harry Potter and how intellectual property creates wealth 14

2.1 Intellectual property as a concept 15

2.2 Scope of intellectual property 18

2.2.1 Patent 19

2.2.2 Utility model 19

2.2.3 Industrial design 20

2.2.4 Mark 20

2.2.5 Copyright 21

2.2.6 Trade secret 22

2.3 Common characteristics of various intellectual property forms $\quad 22$

2.3.1 Intangibility 23

2.3.2 Exclusivity 23

2.3.3 Legality 24

2.3.4 Territoriality 24

2.4 Dialectic rationalization of intellectual property protection 25 
2.5 Academic schools of thought on intellectual property 28

Closer: Badges of allegiance or trademark use? 28

Intellectual property facts: A century of world patents 30

Summary 33

Notes $\quad 34$

References and further reading 36

Chapter 3: Intellectual Property Systems $\quad 39$

Focus and structure $\quad 39$

Opener: The reward system: Virtue or vice? 40

3.1 Three-part nation-based intellectual property systems $\quad 42$

3.2 Intellectual property systems in the US and China compared

3.2.1 Objectives 44

$\begin{array}{ll}3.2 .2 & \text { Legislative guidance } \\ 3.2 .3 & 45\end{array}$

3.2.3 Administrative control 46

3.2.4 Judicial enforcement 50

3.3 An international intellectual property system 51

3.3.1 How does an international intellectual property system function? 51

3.3.2 Issues for an international intellectual property system $\quad 52$

Closer: The utility model: In need of standardization! 55

Intellectual property facts: Grant lags and grant ratios 58

$\begin{array}{ll}\text { Summary } & 62\end{array}$

Notes 63

$\begin{array}{ll}\text { References and further reading } & 65\end{array}$

Part II: Intellectual Property Environments 69

Chapter 4: The Effects of Intellectual Property on

Political Economy $\quad 71$

$\begin{array}{ll}\text { Focus and structure } & 71\end{array}$

Opener: The microchip that has transformed the world 72

4.1 The effects of intellectual property on economic growth 74

4.2 The effects of intellectual property on international trade $\quad 76$

4.3 The effects of intellectual property on foreign direct investment $\quad 78$

4.4 The effects of intellectual property on welfare 79

4.5 The effects of intellectual property on licensing 80

4.6 The effects of intellectual property on technology transfer
and innovation

4.7 Other effects of intellectual property 85

$\begin{array}{ll}\text { Closer: Opening the source of software technology } & 87\end{array}$ 
Intellectual property facts: Measurements of intellectual property systems

Summary

Notes

References and further reading

Chapter 5: The Effects of Political Economy on Intellectual Property

Focus and structure

Opener: Copyright - How copying came to be wrong?

5.1 The effects of political systems on intellectual property 102

5.2 The effects of legal systems on intellectual property

5.3 The effects of economic systems on intellectual property 106

Closer: The 'hot waves' of intellectual property in China

Intellectual property facts: Income, individualism and piracy

Summary

Notes

References and further reading

Chapter 6: The Effects of Culture on Intellectual Property

Opener: Dazzling the world: The Indian software explosion

6.1 Education and intellectual property

6.2 Religion and intellectual property

6.3 Social stratification and intellectual property

6.4 Language and intellectual property

Closer: Color marks: Transcending language barriers, or causing disputes?

Intellectual property facts: Culture and intellectual property in figures

Summary

Notes

References and further reading

Part III: Intellectual Property Management

Chapter 7: Managing Intellectual Property Assets

Focus and structure

Opener: The spies who loved Pemberton

7.1 Corporate contexts and managing intellectual property assets

7.2 Managing intellectual property people

7.2.1 Corporate intellectual property positioning for resources need 
7.2.2 Balancing resources distribution to maximize intellectual property creativity

7.2.3 Internal people-management: The imperatives

7.3 Managing intellectual property products and services

7.3.1 Managing the intellectual property portfolio

7.3.2 Corporate tactics of intellectual property generation, protection and dissemination

Closer: Down to intellectual property - feats and ventures of the Googlers

Intellectual property facts: Intellectual property insurance:

Insure ... or unsure?

Summary

Notes

References and further reading

Chapter 8: Valuing Intellectual Property

Focus and structure

Opener: An intellectual property deal starts with homework

8.1 Varied perceptions of intellectual property value

8.2 Three major valuation methods: Pros and cons

8.2.1 Market approach

8.2.2 Cost approach

8.2.3 Income approach

8.2.4 Method selection

8.3 Other methods in brief

8.4 The significance of intellectual property valuation

Closer: The intellectual property assets of the Green Eggs and Ham man

Intellectual property facts: Royalties for value

Notes

References and further reading

\section{Part IV: Intellectual Property Strategies}

\section{Chapter 9: Commercializing Intellectual Property Internationally}

Focus and structure

Opener: Singing karaoke with the cockroach-killer seller!

9.1 Pre-commercializing evaluation

9.1.1 Intellectual property owner's capacity for profiting internationally

9.1.2 The driving forces behind internationalizing intellectual property 
$\begin{array}{lll}\text { 9.1.3 Targeting countries } & 195\end{array}$

9.1.4 Timing 196

9.2 Internationalizing intellectual property - Costs, profits, risks and control

9.2.1 International intellectual property trade $\quad 197$

9.2.2 Intellectual property turnkey project 199

9.2.3 Intellectual property licensing and franchising 200

9.2.4 Intellectual property joint venture 203

9.2.5 Intellectual property operations with whole ownership abroad 205

9.3 Selecting an appropriate intellectual property strategy 207

Closer: YouTube - Bubble up with intellectual property 209

Intellectual property facts: High impact patents and market leadership 213

Summary 215

Notes 216

$\begin{array}{ll}\text { References and further reading } & 217\end{array}$

Chapter 10: Licensing and Contracting Intellectual Property Internationally 219

Focus and structure $\quad 219$

Opener: Compulsory licensing: Easier said than done! 220

10.1 Licensing and its forms 224

10.2 Licensing relationships 226

10.3 Intellectual property negotiation 231

10.3.1 Negotiation - an art 231

10.3.2 Intellectual property negotiation - a complicated deal 231

10.3.3 Intellectual property negotiation - a team matter 232

10.3.4 Intellectual property negotiation - a protracted process

10.4 Intellectual property licensing contracting and implementation

Closer: Patent trolls: Legitimate dealers or harassers? 242

Intellectual property facts: Underexploited licensing assets attract attention $\quad 245$

Summary $\quad 247$

Notes 248

$\begin{array}{ll}\text { References and further reading } & 249\end{array}$

Chapter 11: Global Piracy and Strategic Responses 251

Focus and structure $\quad 251$

Opener: The Da Vinci Code case and the Smithy Code judgment 252

11.1 Three ways to lose an intellectual property 254 
11.2 Piracy and its typology

11.3 Impact: Where there's intellectual property, there's piracy 258

11.4 Causes: Globalization of piracy 259

11.4.1 Intellectual property environment factors 260

11.4.2 Supply and demand reciprocity 261

11.4.3 Corporate factors 262

11.5 Solutions: Strategic actions for alleviating piracy 263

11.5.1 Prevention is better than cure - proactive approaches

11.5.2 There is no panacea, but a cure is necessary - defensive weapons

11.5.3 External backing and unremitting acts networking means

Closer: Starbucks: Infusing bliss and brewing agony

Intellectual property facts: Piracy quantification - an issue for solution

Summary

Notes

References and further reading

Chapter 12: Understanding and Profiting from Intellectual Property: New Beginnings

Focus and structure

12.1 Fundamental understanding for intellectual property protection

12.2 Intellectual property environment assessment to select profiting base

12.3 Management preparation to equip intellectual property resources

12.4 Strategizing actions to profit from intellectual property 


\section{List of Tables}

Table 2.1 Top 20 countries in terms of the number of invention patent grants (1883-2005)

Table 3.1 A comparison of the patent system between the US and China

Table 3.2 A brief summary of the international intellectual property treaties, conventions and agreements

Table 3.3 A comparison of the grant lags and ratios for invention patents between the US and China (1985-2002)

Table 4.1 Relations between income and intellectual property protection

Table 6.1 Culture and intellectual property in figures

Table 7.1 Eight mistakes to avoid in managing confidential information

Table 8.1 The intellectual property value of the football clubs $(£ 000)$

Table 8.2 Intellectual property costs based on trended cost approach (US\$000)

Table 8.3 Other valuation methods of intellectual property 174

Table 8.4 Valuation differences (US\$ million) 179

Table 8.5 Average royalties by company, product and industry 181

Table 9.1 Compare and contrast licensing and franchising intellectual property

Table 9.2 The pros and cons of internationally commercializing intellectual property

Table 10.1 Recent examples of alliance relationship established in Asia

Table 10.2 Types of negotiators

Table 10.3 Reasons to patent product innovation

Table 11.1 Ten corporate strategies against piracy 


\section{List of Figures}

Figure 1.1 A route map for the book 6

$\begin{array}{lll}\text { Figure 2.1 Construction of corporate assets } & 17\end{array}$

Figure 2.2 The number of invention patent grants in the world (1883-2005)

Figure 3.1 Global applications for and grants of utility models (1975-2002)

Figure 3.2 Global comparison of patent and utility model grants (1975-2002)

Figure 5.1 Piracy-GNI relation (-0.8405) 111

Figure 5.2 Piracy-individualism relation (-0.7673) 111

Figure 6.1 Intellectual property rules, regulations and laws across the hierarchy in China

Figure 6.2 A model of cultural impact on intellectual property 129

Figure 7.1 Corporate contexts and managing intellectual property assets

Figure 7.2 Human resources distribution in the software industry

Figure 7.3 EU country variations in patent insurance 157

Figure 8.1 Value-valuation decision chain 164

$\begin{array}{lll}\text { Figure 8.2 The top } 100 \text { best global brands }(\$ \mathrm{~m}) & 167\end{array}$

Figure 9.1 Relationship between high impact patents and market leadership

Figure 10.1 Different forms of intellectual property licensing depending on the geo-restrictions 225

Figure 10.2 Licensing relationships 226

Figure 11.1 Intellectual property obsolescence cycle 254

Figure 11.2 Types of piracy 256

Figure 11.3 Corporate strategies against piracy 265

Figure 12.1 A route map for actions and challenges 288 


\section{List of Photos}

Photo 2.1 Matthew Reed 29

Photo 4.1 Jack Kilby in $1958 \quad 72$

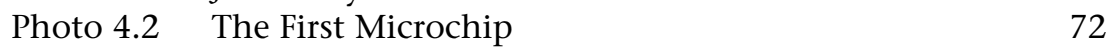

Photo 5.1 The Statute of Anne 100

Photo 7.1 Williams, Dimson and Duhaney (left) on trial 2006-7 139

Photo 9.1 Inoue and the first karaoke machine 191

Photo 9.2 Inoue today 191

Photo 11.1 Starbucks, Xingbake, Starpreya and Excelsior Caffé 276 


\section{List of Opener and Closer Cases}

Chapter 2

Opener

Closer

Chapter 3

Opener

Closer

Chapter 4

Opener

Closer

Chapter 5

Opener

Closer

Chapter 6

Opener

Closer

Chapter 7

Opener

Closer

Chapter 8

Opener

Closer

Chapter 9

Opener

Closer

Chapter 10

Opener

Closer

Chapter 11

Opener

Closer
Harry Potter and how intellectual property creates wealth

Badges of allegiance or trademark use?

The reward system: Virtue or vice?

40

The utility model: In need of standardization!

The microchip that has transformed the world

Opening the source of software technology

Copyright - How copying came to be wrong? $\quad 100$

The 'hot waves' of intellectual property in China 107

Dazzling the world: The Indian software explosion

Color marks: Transcending language barriers, or causing disputes?

The spies who loved Pemberton

Down to intellectual property - feats and ventures of the Googlers

An intellectual property deal starts with homework

163

The intellectual property assets of the Green Eggs and Ham man

Singing karaoke with the cockroach-killer seller!

190

YouTube - Bubble up with intellectual property

209

Compulsory licensing: Easier said than done!

Patent trolls: Legitimate dealers or harassers?

220

242

The Da Vinci Code case and the Smithy Code judgment

Starbucks: Infusing bliss and brewing agony 


\section{List of Intellectual Property Facts}

Chapter 2 A century of world patents 30

Chapter 3 Grant lags and ratios 58

$\begin{array}{llr}\text { Chapter } 4 & \text { Measurements of intellectual property systems } & 91\end{array}$

Chapter 5 Income, individualism and piracy 110

Chapter 6 Culture and intellectual property in figures 128

Chapter 7 Intellectual property insurance: Insure ... or unsure? 156

Chapter 8 Royalties for value 180

Chapter 9 High impact patents and market leadership 213

Chapter 10 Underexploited licensing assets attract attention 245

Chapter 11 Piracy quantification - an issue for solution 277 


\section{List of Abbreviations and Acronyms}

AIDS Acquired Immune Deficiency Syndrome

BBC British Broadcasting Corporation

BSA Business Software Alliance

CEO Chief Executive Officer

CHF Swiss Franc

CNN Cable News Network

CN¥ Chinese Currency Renminbi Yuan

DNA Deoxyribonucleic Acid

DVC The Da Vinci Code

ECJ European Court of Justice

EPO European Patent Office

EU European Union

FBI Federal Bureau of Investigation

FDI Foreign Direct Investment

4Ps The Personal, the Persuader, the Practical and the Precise

GDP Gross Domestic Product

GNI Gross National Income

GNP Gross National Product

GSM Global System for Mobile Communications

HBHG The Holy Blood and The Holy Grail

HIV Human Immunodeficiency Virus

HQ Headquarters

IB International Business

IBM International Business Machines Corporation

IC Intellectual Capital

ID Industrial Design

IIT Indian Institute of Technology

INTA International Trademark Association

IP Intellectual Property

IPI Intellectual Property Integration

IPP Intellectual Property Protection

IPS Intellectual Property System

IPV Intellectual Property Value

ISP Internet Service Provider

IT Information Technology

JEDEC Joint Electron Device Engineering Council 


$\begin{array}{ll}\text { JPO } & \text { Japan Patent Office } \\ \text { JV } & \text { Joint Venture } \\ \text { KFC } & \text { Kentucky Fried Chicken } \\ \text { KTV } & \text { Karaoke Box or Karaoke Music Video } \\ \text { LDCs } & \text { Least-Developed Countries } \\ \text { MA } & \text { Master of Arts } \\ \text { MBA } & \text { Master of Business Administration } \\ \text { MIP } & \text { Managing Intellectual Property } \\ \text { MNEs } & \text { Multinational Enterprises } \\ \text { MOU } & \text { Memorandum of Understanding } \\ \text { MU PLC } & \text { Manchester United Public Limited Company } \\ \text { NBC } & \text { National Broadcasting Company } \\ \text { NGO } & \text { Non-Governmental Organization } \\ \text { NPC } & \text { National People's Congress } \\ \text { NT } & \text { Net Tangible Assets (Total Tangible Assets - Total Liability) } \\ \text { OECD } & \text { Organization for Economic Cooperation and Development } \\ \text { OSI } & \text { Open Source Initiative } \\ \text { OSS } & \text { Open Source Software } \\ \text { PPP } & \text { Purchasing Power Parity } \\ \text { PRC } & \text { People's Republic of China } \\ \text { P2P } & \text { Peer to Peer or Person to Person } \\ \text { PWL } & \text { Priority Watch List } \\ \text { R\&D } & \text { Research and Development } \\ \text { RCA } & \text { Radio Corporation of America } \\ \text { RIM } & \text { Research in Motion } \\ \text { SIPO } & \text { State Intellectual Property Office, the People's Republic of } \\ & \text { China } \\ \text { SMEs } & \text { Small- and Medium-sized Enterprises } \\ \text { TCAs } & \text { Treaties, Conventions and Agreements } \\ \text { TI } & \text { Texas Instruments } \\ \text { TRIPS } & \text { Agreement on the Trade-Related aspects of Intellectual } \\ & \text { Property Rights } \\ \text { UD } & \text { Utility Model } \\ \text { UNCTAD } & \text { United Nations Conference on Trade and Development } \\ \text { UNESCO } & \text { United Nations Educational, Scientific and Cultural } \\ & \text { Organization } \\ \text { UPOV } & \text { International Union for the Protection of New Varieties } \\ & \text { of Plants } \\ \text { US } & \text { United States of America } \\ \text { USC35 } & \text { US Code Title 35 - Patent } \\ \text { US\$ } & \text { US dollar } \\ & \\ \text { PO }\end{array}$


xx List of Abbreviations and Acronyms

USPTO US Patents and Trademarks Office

USTR US Trade Representative

WHO World Health Organization

WIPO World Intellectual Property Organization

WOE Wholly Owned Enterprise

WTO World Trade Organization

WWII World War Two 


\section{Preface and Acknowledgements}

This book addresses a dual audience of practitioners and analysts dealing with IP-related business and analysis in the world business. Business practitioners, including business managers and intellectual property (IP) owners who intend to commercialize their IP can gain a systematic understanding of the links between IP and business and how IP generates profits towards corporate success. This book will also enable IP practitioners to devise a plan based on logically adopted strategic and managerial approaches to commercializing an IP in a particular country. It enables business practitioners to critically scrutinize their IP within world business in a holistic manner from examining the IP environment to assessing IP management and IP strategies. It also enables business practitioners to critically evaluate their IP in an extensive manner bearing in mind IP creation, protection and dissemination.

This book also serves a purpose of equipping IP analysts (corporate analysts and academic researchers) with enhanced IP analytical skills to serve both research and practice. With the guidance of this book, IP analysts will be able to sharpen their ability to analyse IP activities across borders, to understand international innovative and technological activities and evolve appropriate responses and solutions from corporate, industrial and international perspectives. This book also serves as a helpful text to provide postgraduate business and management students with: a critical understanding on IP theory and practice from the perspective of international managers; an appreciation of the strategic importance of IP to corporate success; and a comprehensive understanding of how IP is managed and commercialized. It delineates various IP themes both theoretically and empirically from the international business angle with the help of supporting cases and statistics. It is, therefore, a source of literature for IP to lead to further studies.

In the process of writing this book, I have been endowed with superb support from friends across the world in various ways and my profound thanks are expressed here as a gesture of my sincere gratitude. They are (in alphabetical order) M. R. Abdulhamid, P. Clarke, J. Leontiades, J. Morgan, R. Ni, H. Ntchatcho, M. Pautasso, W. Qu, N. Sabharwal, M. Sonmez and Geoffrey Yu.

My special thankfulness is dedicated to all the managers, national government officials and all the division directors from the World Intellectual Property Organization, United Nations whom I have interviewed. Without their support, the data presented in this book would be scarce and unoriginal. 
I would also like to express my appreciation to several IP owners. I wish to thank them for giving me permission to use their copyrighted photos. The use has been acknowledged separately when photos appear within the book.

I would also thank the Palgrave Macmillan Publishing Group for making this book available to business practitioners and analysts. Many people within the group that I do not know have made a contribution in the publishing process of the book, and I sincerely appreciate their effort. I am grateful to Emily Bown, Linda Auld and Mervyn Thomas because I have benefited from their kindest assistance in the production process. My special thanks go to Virginia Thorp, Senior Commissioning Editor at the Business and Management division for her patience, enthusiasm and assistance in the process of the book's publication, particularly for her help to finalize the book publication contract.

Last and not the least, my beyond-word gratitude belongs to my family and my soul friends. Their unconditional love and support have given me the confidence and strength to complete this book.

Deli Yang

Bradford, West Yorkshire, England

October 2007 